\title{
POTENSI EFISIENSI PEMASARAN PINANG TERHADAP SOSIAL EKONOMI DI KECAMATAN BETARA KABUPATEN TANJUNG JABUNG BARAT PROVINSI JAMBI
}

\author{
Suharyon \\ Balai Pengkajian Teknologi Pertanian (BPTP) Jambi \\ suharyonhariyon@gmail.com
}

\begin{abstract}
ABSTRAK
Sektor perkebunan merupakan salah satu subsektor yang mempunyai kontribusi penting dalam hal penciptaan nilai tambah yang tercermin dari kontribusinya terhadap produk domestik bruto (PDB). Beberapa komoditas perkebunan yang dianggap penting di Indonesia, seperti: karet, kelapa sawit, kelapa, kopi, pinang, kakao, teh, dan tebu merupakan komoditas unggulan yang menyumbang devisa bagi negara secara rutin. Kelapa sawit, karet dan pinang merupakan komoditas tanaman yang di ekspor ke berbagai Negara lain yang membutuhkan. Kegiatan ekspor tersebut berkaitan dengan tingkat keuntungan pengusahaan komoditas tersebut relatif lebih baik dan juga kebijakan pemerintah untuk mendorong perluasan areal komoditas tersebut guna meningkatkan jumlah produksi. Harga jual pinang di Kecamatan Betara dengan kualitas pinang kering ditingkat petani sebagai produsen Rp 10.000 sedangkan ditingkat pedagang pengumpul yang hendak disalurkan ke Perusahaan Eksportir sebesar Rp 15.000,00. Lembaga pemasaran pinang di Kecamatan Betara terdiri dari tiga pola saluran lembaga pemasaran, yaitu: 1) petani-PPB-perusahaan eksportir; 2) petani-PPK-PPBperusahaan eksportir; 3) petani-PPK-perusahaan eksportir. Fungsi pemasaran yang dilakukan oleh lembaga-lembaga pemasaran, yaitu fungsi pertukaran, fungsi fisik dan fungsi fasilitas. Berdasarkan struktur pasar, pemasaran pinang di Kecamatan Betara cenderung mengarah kepada struktur pasar oligopsoni. Dilihat dari perilaku pasar, lembaga pemasaran yang terlibat memiliki perilaku yang berbeda-beda. Sedangkan berdasarkan kinerja pasar menunjukkan bahwa nilai marjin, farmer's share, dan rasio keuntungan tidak merata pada masing-masing lembaga pemasaran. Berdasarkan indikator SCP yang telah dijelaskan dapat diketahui bahwa pemasaran pinang di di Kecamatan Betara belum efisien. Berdasarkan kondisi saat ini dan hasil analisis yang telah dilakukan, saluran pemasaran I (petani-PPB-perusahaan eksportir) merupakan alternatif saluran pemasaran yang efisien yang dapat dipilih oleh petani pinang.
\end{abstract}

\section{Kata Kunci : Pinang, Pemasaran, Lembaga, Pendapatan Petani}

\section{PENDAHULUAN}

Provinsi Jambi mempunyai tiga wilayah yang menjadi sentra komoditi pinang yang berkualitas baik di Indonesia. Seperti di Kabupaten Tanjung Jabung Barat, Tanjung Jabung Timur dan Kabupaten Muaro Jambi. Bahkan, komoditi pinang yang ada di tiga daerah itu merupakan yang paling banyak koleksi plasma nutfahnya, sehingga tidak sedikit negara asing yang menjadi tujuan ekspor pinang asal ketiga daerah itu juga berminat membeli pinang asal Provinsi Jambi tersebut. Dari hasil penelitian yang baru-baru ini yang dilaksanakan Balai Penelitian Kelapa dan Pinang Manado, di ketiga daerah itu menyebutkan, kualitas komoditi pinang yang ada di Provinsi Jambi jauh lebih baik dari kualitas komoditi pinang yang ada di 
Nanggroe Aceh Darussalam (NAD). Dan ini tentunya, terkait rendahnya kadar air komoditi pinang yang dihasilkan di tiga daerah penghasil pinang di Jambi (Miftahurrocman, 2013).

Provinsi Jambi sebagai sentra penyebaran pinang terbesar di Indonesia memiliki potensi keragaman genetik plasma nutfah pinang yang luas. Selain untuk sumber daya genetik dalam rangka program pemuliaan tanaman juga dapat dikembangkan untuk peningkatan kesejahteraan petani. Keadaan luas lahan, produksi dan produktivitas pinang di Provinsi Jambi Tahun 2015, sebagai berikut:

Tabel 1. Luas Lahan, Produksi dan Produktivitas Pinang di Provinsi Jambi Tahun 2015

\begin{tabular}{|c|c|c|c|c|c|c|}
\hline \multirow{2}{*}{ Kabupaten/Kota } & \multicolumn{3}{|c|}{ Luas Lahan (ha) } & \multirow{2}{*}{ Jumlah } & \multirow{2}{*}{$\begin{array}{c}\text { Produksi } \\
\text { (ton) }\end{array}$} & \multirow{2}{*}{$\begin{array}{c}\text { Produktivitas } \\
\text { (ton/ha) }\end{array}$} \\
\hline & TBM & TM & TTM & & & \\
\hline Batanghari & - & 27 & 2 & 29 & 17 & 0.63 \\
\hline Muaro Jambi & 60 & 83 & 13 & 156 & 11 & 0.13 \\
\hline Bungo & 35 & 64 & 13 & 112 & 33 & 0.52 \\
\hline Tebo & 39 & 147 & 12 & 198 & 21 & 0.14 \\
\hline Merangin & 79 & 174 & 14 & 267 & 52 & 0.31 \\
\hline Sarolangun & 47 & 118 & 78 & 243 & 26 & 0.22 \\
\hline Tanjung Jabung Barat & 2.330 & 7.335 & 217 & 9.882 & 10.518 & 1.43 \\
\hline Tanjung Jabung Timur & 2.254 & 6.238 & 402 & 8.894 & 2.754 & 0.44 \\
\hline Kerinci & 38 & 54 & 29 & 121 & 22 & 0.41 \\
\hline Sungai Penuh & 22 & 42 & 3 & 67 & 37 & 0.88 \\
\hline Jumlah & 4.904 & 14.282 & 783 & 19.969 & 13.482 & 0.51 \\
\hline
\end{tabular}

Sumber :Dinas Perkebunan Provinsi Jambi, 2016

Dari Tabel 1 dapat disimpulkan bahwa luas lahan penanaman terluas terdapat di wilayah pantai timur, yaitu di Kabupaten Tanjung Jabung Barat ( 9.882 ha) dengan produktivitas 1.43 ton/ha dan Kabupaten Tanjung Jabung Timur (8.894 ha) dengan produktivitas 0.44 ton/ha. Tanaman pinang di Provinsi Jambi banyak yang dikembangkan secara polikultur/tumpang sari dengan tanaman yang lain, seperti; tanaman kopi, kelapa, kelapa sawit, pisang; dengan jarak tanam $\pm 3 \times 3 \mathrm{~m}$ (populasi \pm 1000 tanaman/ha) (BPS Provinsi Jambi, 2016). Berikut merupakan tabel luas lahan, produksi serta produktivitas pinang di Kabupaten Tanjung Jabung Barat pada tahun 2011-2015. (Dinas Perkebunan, 2016).

Kabupaten Tanjung Jabung Barat mempunyai 13 Kecamatan yang sebagian besar melakukan kegiatan budidaya pinang. Kecamatan yang melakukan budidaya pinang diantaranya Kecamatan Tungkal Ulu, Batang Asam, Tebing Tinggi, Muara Papalik, Pengabuan, Senyerang, Tungkal Ilir, Bram Itam, Seberang Kota, Betara dan Kuala Betara. Berikut ini merupakan tabel 2 luas lahan, produksi dan produktivitas pinang perkecamatan di Kabupaten Tanjung Jabung Barat. (Dinas Perkebunan Kabupaten Tanjung Jabung Barat, 2016). 
Tabel 2.Keadaan Luas Lahan, Produksi dan Produktivitas Pinang Perkecamatan di Kabupaten Tanjung Jabung Barat tahun 2015

\begin{tabular}{|c|c|c|c|c|c|c|}
\hline \multirow{2}{*}{ Kecamatan } & \multicolumn{3}{|c|}{ Luas Lahan (ha) } & \multirow{2}{*}{ Jumlah } & \multirow{2}{*}{$\begin{array}{l}\text { Produksi } \\
\text { (ton) }\end{array}$} & \multirow{2}{*}{$\begin{array}{c}\text { Produktivitas } \\
\text { (ton/ha) }\end{array}$} \\
\hline & TBM & TM & TTM & & & \\
\hline Tungkal Ilir & 123 & 406 & - & 529 & 512 & 1.26 \\
\hline Seberang Kota & 174 & 402 & 54 & 630 & 694 & 1.73 \\
\hline Bram Itam & 343 & 787 & 111 & 1.241 & 1.175 & 1.50 \\
\hline Tungkal Ulu & 11 & 14 & 2 & 27 & 19 & 1.36 \\
\hline Tebing Tinggi & 27 & 39 & - & 66 & 52 & 1.33 \\
\hline Batang Asam & 4 & 16 & - & 20 & 12 & 0.75 \\
\hline Merlung & - & - & - & - & - & - \\
\hline Renah Mendaluh & - & - & - & - & - & - \\
\hline Muara Papalik & 1 & 7 & - & 8 & 12 & 1.71 \\
\hline Betara & 72 & 864 & 13 & 944 & 1.029 & 1.20 \\
\hline Kuala Betara & 71 & 833 & - & 904 & 1.253 & 1.50 \\
\hline Pengabuan & 1.293 & 3.348 & 39 & 4.680 & 4.833 & 1.44 \\
\hline Senyerang & 210 & 619 & 3 & 832 & 927 & 1.50 \\
\hline Jumlah & 2.329 & 7.335 & 222 & 9.882 & 10.518 & 1.39 \\
\hline
\end{tabular}

Sumber :Dinas Perkebunan Kabupaten Tanjung Jabung Barat, 2016

Sesuai data Tabel 2 dapat diketahui bahwa produktivitas pinang di Kecamatan Betara menduduki peringkat ke tiga dengan luas lahan sebesar 944 ha. Meskipun demikian, berdasarkan hasil evaluasi melalui sidang pelepasan varietas tanggal 8 November 2012, populasi Pinang Betara telah dilepas sebagai pinang unggul dengan SK MENTAN Nomor 199/Kpts/SR.120/1/2013, sebagai materi pengembangan pinang pada daerah-daerah yang memiliki iklim seperti di Kabupaten Tanjung Jabung Barat. Adapun karakteristik yang dimiliki Pinang Betara adalah : umur mulai berbunga Pinang Betara adalah $4-5$ tahun dan umur mulai panen $6-7$ tahun. (Miftahorrachman, 2015).Tahun 2015, pinang menjadi andalan ekspor Provinsi Jambi kebeberapa negara seperti Singapura, Malaysia dan India. Berikut merupakan data perkembangan luas lahan, produktivitas tenaga kerja dan volume ekspor komoditas pinang di Provinsi Jambi dari tahun 2011-2015:

Tabel 3. Data Luas Lahan, Produksi Tenaga Kerja dan Volume Ekspor Komoditas Pinang di Provinsi Jambi tahun 2011-2015

\begin{tabular}{rcrrrr}
\hline \multirow{2}{*}{ Tahun } & \multirow{2}{*}{$\begin{array}{c}\text { Luas lahan } \\
\text { (ha) }\end{array}$} & \multirow{2}{*}{$\begin{array}{c}\text { Produksi } \\
\text { (ton) }\end{array}$} & T K & \multicolumn{2}{c}{ Volume Ekspor } \\
\cline { 5 - 6 } & 18.204 & 16.508 & 27.889 & 57.835 .810 & Nong) \\
\hline 2011 & 18.637 & 16.185 & 27.907 & 39.667 .330 & 27.782 .353 \\
2012 & 18.715 & 16.297 & 28.049 & 36.413 .540 & 26.914 .006 \\
2013 & 18.899 & 15.447 & 28.270 & 38.496 .890 & 42.920 .453 \\
2014 & 19.969 & 13.482 & 28.069 & 62.206 .100 & 71.551 .603 \\
\hline
\end{tabular}

Sumber : Dinas Perkebunan Provinsi Jambi, 2016 
Berdasarkan Tabel 3 dapat diketahui bahwa volume ekspor $(\mathrm{Kg})$ mengalami fluktuasi setiap tahunnya, yakni mengalami penurunan pada tahun 2012 hingga tahun 2013 dari $57.835 .810 \mathrm{~kg}$ menjadi $36.413 .540 \mathrm{~kg}$ hal ini disebabkan oleh kondisi iklim beberapa wilayah di Provinsi Jambi yang tidak baik, kemudian kembali mengalami peningkatan pada tahun tahun 2014 hingga 2015 dari $38.496 .890 \mathrm{~kg}$ menjadi $62.206 .100 \mathrm{~kg}$, hal ini disebabkan oleh kondisi iklim beberapa wilayah di Provinsi Jambi yang telah kembali normal. Pemasaran pinang di Kecamatan Betara secara umum dipasarkan di Pasar lokal dan diekspor dengan Negara tujuan ekspor yaitu Singapore dan India. Salah satu kendala pemasaran Pinang Di Kecamatan Betara adalah saluran pemasaran yang panjang melibatkan banyak lembaga pemasaran. Semakin panjang saluran pemasaran, harga ditingkat konsumen akan semakin tinggi, sehingga keuntungan dari tingginya harga tidak dinikmati petani melainkan pedagang perantara. Oleh sebab itu, dikhawatirkan perbedaan marjin pemasaran yang tinggi akan merugikan petani sebagai produsen. Setiap lembaga pemasaran pinang yang terlibat melaksanakan fungsi-fungsi pemasaran. Fungsi - fungsi pemasaran yang dilakukan oleh masing-masing lembaga pemasaran tersebut mengakibatkan bertambahnya biaya pemasaran. Sehingga semakin panjang saluran pemasaran maka semakin tinggi biaya yang dikeluarkan sehingga semakin tinggi pula harga pinang yang dibayarkan Perusahaan Eksportir. Oleh sebab itu diindikasikan pemasaran pinang tersebut tidak efisien. Efisiensi pemasaran pada saluran pemasaran pinang dapat dilihat dengan menggunakan pendekatan SCP (Structure, Conduct, and Performance). SCP merupakan pendekatan yang digunakan untuk mengukur efisiensi pemasaran dengan melihat struktur pasar, perilaku pasar dan keragaan pasar pada masingmasing lembaga pemasaran. Struktur pasar dapat mempengaruhi perilaku pasar pinang. Struktur pasar dan perilaku pasar akan menentukan tingkat efisiensi dari pemasaran pinang. Keragaan pasar digunakan untuk melihat seberapa jauh pengaruh struktur dan perilaku pasar dalam proses pemasaran komoditas pinang.

\section{METODE PENELITIAN}

\section{Metode Pelaksanaan Pengkajian}

Pengkajian ini dilaksanakan di Kecamatan Betara, Kabupaten Tanjung Jabung Barat, Provinsi Jambi dari bulan Agustus sampai dengan bulan Sptember 2017. Pemilihan lokasi dilakukan secara sengaja (purposive), dengan pertimbangan bahwa Kabupaten Tanjung Jabung Barat merupakan salah satu penghasil pinang terbesar di Provinsi Jambi dengan kualitas produksi pinang yang dihasilkan dengan hasil terbaik yakni berada di Kecamatan Betara. Objek dalam kegiatan ini adalah petani yang berusahatani pinang dan mempunyai kebun pinang serta hasil dari pemasaran tersebut sangat membantu dalam memenuhi kebutuhan keluarga yang berdomisili di desa responden dan pedagang pinang. Untuk menentukan petani sampel secara acak sederhana (simple Random Sampling). Kegiatan dibatasi pada struktur pasar pinang di tingkat produsen, lembaga pemasaran, saluran pemasaran, keragaan pasar, struktur pasar, margin pemasaran, besarnya harga yang diterima petani dan efisiensi pemasaran. 


\section{Sumber Data}

Sumber data adalah data primer dan data sekunder. Data primer diperoleh melalui wawancara dengan responden yang terpilih menjadi sampel dalam pengkajian ini, yakni bersumber dari petani pinang. Responden pedagang atau lembaga pemasaran lain yang terkait diperoleh berdasarkan alur pemasaran pinang oleh petani, sedangkan data sekunder adalah data yang bersumber dari studi pustaka, website, Badan Pusat Statistik (BPS), Dinas Perkebunan Provinsi Jambi dan bebagai instansi terkait di Kabupaten Tanjung Jabung Barat. Pengumpulan data yang digunakan yaitu metode survei dengan teknik wawancara responden. Angket atau kuisioner adalah alat yang digunakan dalam pengumpulan data melalui formulirformulir yang berisi pertanyaan-pertanyaan yang diajukan secara tertulis pada seseorang atau sekumpulan orang untuk mendapatkan jawaban atau tanggapan dan informasi yang diperlukan, kuisioner merupakan data primer dalam penelitian ini (Sugiyono, 2014).

\section{HASIL DAN PEMBAHASAN}

\section{Gambaran Umum Daerah Pengkajian}

Daerah yang menjadi objek adalah Kecamatan Betara Kabupaten Tanjung Jabung Barat. Pada bagian ini akan menjelaskan tentang letak geografis, keadaan penduduk, sarana dan prasana penunjang pertanian dan mata pencarian penduduk. Kecamatan Betara merupakan salah satu Kecamatan yang termasuk dalam wilayah Kabupaten Tanjung Jabung Barat Provinsi Jambi, dengan luas 541,90 $\mathrm{Km}^{2}$ yang terdiri dari 12 desa, dengan ketinggian 3 meter dari permukaan laut. Pusat pemerintahan Kecamatan Betara berada di Desa Mekar Jaya. Jumlah penduduk yang bermukim di Kecamatan Betara sampai tahun 2015 yaitu 2.618 jiwa terdiri dari laki-laki 1.340 jiwa dan perempuan 1.278 jiwa. Mata pencaharian penduduk di Kecamatan Betara sebagian besar masih bertumpu pada sektor pertanian, hal ini juga mempengaruhi oleh tingkat pendidikan, jumlah penduduk, sarana dan prasarana yang ada dan lain sebagainya. Selain itu terdapat beberapa sektor lainnya yang juga merupakan mata pencaharian penduduk di Kecamatan Betara.

\section{Budidaya Komoditas Pinang}

Tanaman pinang dapat tumbuh di segala jenis tanah pada ketinggian antara $0-1.400$ meter di atas permukaan laut (dpl), tetapi ketinggian idealnya berkisar antara $0-750 \mathrm{~m}$ dpl. Miskipun pinang dapat tumbuh pada berbagai jenis tanah namun supaya pertumbuhannya baik memerlukan tanah yang banyak mengandung unsur hara serta tidak berbatu atau berkapur. (Ditjenbun, 2015). Pinang membutuhkan sinar matahari yang cukup dan tidak terdapat genangan air, sedangkan suhu lingkungan yang diperlukan berkisar antara $20-30^{\circ} \mathrm{C}$, dengan curah hujan antara $2.000-3.000 \mathrm{~mm}$ per tahun ( Sulkani, 2013).

Tanaman ini dapat beradaptasi dengan baik di daerah iklim tropis lembab dan tumbuh pada berbagai kondisi tanah di India, Sri Langka, Asia Tenggara, Papua New Guinea dan Kepulauan Pasifik. (Sastrahidajat dan Soemarno, 1986). Pohon pinang memilki ciri - ciri tinggi yang lurus bisa mencapai ketinggian 25 meter dan tajuknya yang tidak rimbun, pelepah daunnya berbentuk seperti tabung dengan panjang mencapai $80 \mathrm{~cm}$ dan bagian ujung daunnya 
tampak sobek, selain pohonnya yang biasa digunakan untuk lomba memanjat pinang, tumbuhan ini juga mempunyai buah yang ternyata banyak dimanfaatkan untuk berbagai jenis penyakit. Zat yang dikandung di dalam buah pinang meliputi : arecolidine, arecaidine, guvacoline, guracine dan beberapa senyawa lainnya. Sedangkan biji tanaman ini yang juga bermanfaat memiliki kandungan alkaloida seperti arekaina dan arekolina yang bersifat adiktif dan dapt merangsang otak (Yuyu Yuhannah, 2014 ).

Secara rinci dan sistematika pinang diuraikan sebagai berikut :

Divisi : Plante

Klas : Monokotil

Ordo : Arrecales

Famili : Arrecaceae atau Palmae ( Palem - Paleman)

Genus : Arreca

Spesies: Arreca catecha

Budidaya pinang tidak sulit dan tidak memerlukan perlakukan khusus yang penting apabila akan mengusahakan tanaman ini secara komersial harus mempunyai lahan yang cukup luas.

1. Persiapan bahan tanaman

Bahan tanam yang digunakan dalam pengembangan pinang adalah dengan biji dari buah yang benar - benar sudah tua. Biji yang akan dijadikan benih harus diambil dari pohon induk yang berumur kira - kira 15 tahun atau lebih. Produksi buah dari pohon induk setiap tahunnya menghasilkan sekitar 350 butir per pohon.

Cara perbanyakan untuk pinang yaitu :

a. Pembibitan pinang dilakukan dalam bedengan khusus dengan ukuran tergantung keperluan

b. Tanah bedengan untuk tempat persemaian terlebih dahulu digemburkan dan dicampur pupuk kandang serta pasir dengan perbandingan 1:1:1

c. Buah pinang yang hendak dibibitkan terlebih dahulu direndam dalam air selama 3 hari

d. Buah pinang tidak perlu dikupas atau dibuang kulitnya sebelum ditanam

e. Setelah perendaman buah calon bibit selesai, kemudian langsung disemaikan dengan cara membenamkan pada bedengan yang sudah disiapkan

f. Jarak tanam di pesemaian $15 \times 30 \mathrm{~cm}$

g. Setelah biji ditanam lalu ditutup dengan tanah gembur setebal $10 \mathrm{~cm}$

h. Bedengan diberi naungan dan tiap 3 hari sekali dilakukan penyiraman secukupnya

i. Bedengan diberi naungan dan tiap 3 hari sekali dilakukan penyiraman secukupnya

j. Setelah proses pembibitan dilakukan dengan cara yang benar, maka dalam 1 buah biji akan mulai berkecambah dan pada umur 3 bulan tunasnya akan muncul dipermukan tanah

k. Setelah berumur 6 bulan bibit siap ditanam di lapangan

2. Penanaman Untuk pinang hendaknya ditanam pada awal musim hujan, jarak tanam di lapangan bervariasi yaitu : $250 \times 250 \mathrm{~cm}$ atau $250 \times 500 \mathrm{~cm}$ dengan ukuran lubang tanam 50 × 50 × $50 \mathrm{~cm}$ Setelah bibit ditanam kemudian disekelilingnya ditimbun dengan tanah yang sudah dicampur pupuk kandang atau kompos secukupnya dan NPK sebanyak 50 75 gram untuk setiap lubang tanam. Lubang tanam dibuat sekitar $4-8$ minggu sebelum 
penanam bibit dan dibiarkn terbuka terus menerus untuk menerima sinar matahari penuh sekitar $2-4$ minggu

3. Pemeliharaan Pada tahun I ( pertama ) sebaiknya dilakukan 3 kali penyiangan untuk mencegah tumbuhnya rumput atau gulma lain yang tumbuh disekitar tanaman pinang. Jenis dan dosis pemupukan yang digunakan dapat disesuaikan dengan kebutuhan atau tergantung pada tingkat kesuburan tanah. Cara pemberian pupuk baik pupuk kandang maupun pupuk kompos atau buatan dengan membenamkan disekeliling tanaman tepat dibawah tajuk daun. (Anonim, 2008)

\section{Sosial Ekonomi Komoditas Pinang}

Pada umumnya tanaman pinang digunakan sebagai stimulansia dicampur dengan sirih, kapur dan tembakau. Penggunaan buah pinang selain untuk ramuan sirih pinang, juga dimanfaatkan sebagai bahan baku industri dan farmasi. Di bidang industri digunakan dalam penyamakan kulit, pewarna kain dan kapas. Pinang juga dimanfaatkan untuk bidang farmasi yaitu sebagai campuran pembuat obat-obatan seperti obat disentry, cacing, obat kumur dan lain-lain (Miftahorachman, 2015).

Tabel 4. Ekspor Biji Pinang Indonesia 2011-2015

\begin{tabular}{crc}
\hline \multirow{2}{*}{ Tahun } & \multicolumn{2}{c}{ Volume Ekspor } \\
\cline { 2 - 3 } & Volume (Kg) & Nilai (US \$) \\
\hline 2011 & 57.835 .810 & 54.334 .387 \\
2012 & 39.667 .330 & 27.782 .353 \\
2013 & 36.413 .540 & 26.914 .006 \\
2015 & 38.496 .890 & 42.920 .453 \\
\hline
\end{tabular}

Sumber: Dinas Perkebunan Provinsi Jambi, 2016 (diolah)

Sesuai data Tabel 4 perkembangan ekspor biji pinang Indonesia antara tahun 2011 sampai tahun 2015 menunjukkan angka yang selalu berfluktuasi. Tetapi sejak tahun 2013 hingga tahun 2015 menunjukkan trend yang semakin meningkat, bukan hanya nilai tetapi juga volumenya. Dari data Tabel 5 terlihat bahwa dalam kurun 5 tahun (2011 sampai 2015), ekspor biji pinang Indonesia mencatat rekor volume dan nilai tertinggi dicapai pada tahun 2015 . Pinang di pasaran Internasional dikenal sebagai areca nut atau battle nut dapat diekspor dalam bentuk kupasan (biji saja) dan bentuk masih utuh. Bentuk biji lebih disukai importir. Oleh sebab itu, wajar saja bila jumlah ekspornya terus mengalami peningkatan, sedangkan pinang dalam bentuk buah menujukkan tendensi menurun jumlah ekspornya (Nazaruddin, 1993).

\section{Pengalaman Berusahatani Petani Sampel}

Pengalaman berusahatani merupakan pengalaman seseorang dalam berusahatani yang menjadi tolak ukur kemampuan dan keterampilan dalam mengelola pengembangan usahataninya di masa yang akan datang. Pengalaman usahatani mempengaruhi inisiatif petani dalam pengambilan keputusan dan kebijaksanaan dalam mengelola usahataninya. Semakin lama kegiatan yang telah dilakukan maka semakin banyak pula pengalaman yang diperoleh petani. Pengalaman berusahatani dalam berusahatani pinang dihitung berdasarkan tahun 
pertama kali petani memulai usahataninya. Lamanya petani berusahatani pinang ini dinyatakan dalam tahun. Untuk lebih jelasnya pengalaman petani sampel dapat dilihat pada tabel 5 berikut:

Tabel 5. Karakteristik Pengalaman Usahatani Petani Sampel di Daerah Penelitian Tahun 2017

\begin{tabular}{|c|c|c|}
\hline Pengalaman UT (tahun) & Frekuensi (orang) & Persentase $(\%)$ \\
\hline $9-13$ & 23 & 37,70 \\
\hline $14-18$ & 12 & 19,67 \\
\hline $19-23$ & 7 & 11,48 \\
\hline $24-28$ & 7 & 11,48 \\
\hline $29-33$ & 6 & 9,83 \\
\hline $34-38$ & 5 & 8,20 \\
\hline $39-43$ & 1 & 1,64 \\
\hline Jumlah & 61 & 100 \\
\hline
\end{tabular}

Tabel 5 menunjukkan bahwa frekuensi petani terbesar berdasarkan pengalaman berusahatani adalah 9 sampai 13 tahun, yakni sebanyak 23 orang dengan persentase 37,70\%. Pada umumnya petani memperoleh pengalaman dan pengetahuan mengenai budidaya dan usahatani pinang secara otodidak dan secara turun-temurun yang selanjutnya akan mempengaruhi proses adopsi inovasi. Pengalaman berusahatani juga akan mempengaruhi pola pikir dan keputusan petani dalam mengembangkan usahataninya dimasa yang akan datang. Semakin lama pengalaman berusahataninya maka semakin banyak pula pengetahuan nya.

\section{Luas dan Kepemilikan Lahan}

Lahan merupakan faktor produksi yang paling penting dalam usahatani. Luas lahan yang dimaksud adalah luas lahan yang diusahakan adalah luas lahan jagung yang dimilki oleh petani. Menurut Mubyarto (1995), luas lahan garapan merupakan salah satu faktor yang mempengaruhi produksi dan pendapatan petani. Untuk lebih jelasnya dapat dilihat pada tabel berikut:

Tabel 6. Karakteristik Luas Lahan Pinang Petani Sampel Tahun 2017

\begin{tabular}{ccc}
\hline Luas Lahan $\left.\mathbf{( m}^{\mathbf{2}}\right)$ & Frekuensi (orang) & Persentase (\%) \\
\hline $500-858.2$ & 6 & 9,84 \\
$858.3-1216.4$ & 26 & 42,62 \\
$1216.5-1574.7$ & 6 & 9,84 \\
$1574.8-1933$ & 0 & 0 \\
$1933.1-2291.3$ & 16 & 26,23 \\
$2291.4-2649.5$ & 2 & 3,28 \\
$2649.6-3007.8$ & 5 & 8,19 \\
\hline Jumlah & 61 & 100 \\
\hline
\end{tabular}

Sebanyak $80.3 \%$ petani pinang di Kecamatan Betara melakukan usahatani pinang dengan status lahan milik sendiri (Lampiran 3). Ada juga lahan yang digunakan petani sampel yang merupakan lahan garapan/milik orang lain, sedangkan untuk luas lahan pinang terbanyak 
yang ditanami oleh petani, sebanyak 26 orang petani (42.62\%) menggarap lahan seluas 858.3-1216.4 $\mathrm{m}^{2}$. Sedangkan luas lahan rata-rata yang digunakan petani untuk berusahatani pinang adalah $1500 \mathrm{~m}^{2}$.

\section{Karakteristik Lembaga Pemasaran Pinang}

Setelah dilakukan pengkajian terdapat beberapa lembaga pemasaran yang terlibat dalam sistem pemasaran pinang di Kecamatan Betara, yakni Pedagang Pengumpul Kecil (PPK) dan pedagang pengumpul besar (PPB). Kedua pedagang tersebut berdomisili di setiap desa terpilih sebagai tempat penelitian, yang membedakan dari kedua pedagang tersebut adalah jumlah volume pembelian pinang dari petani maupun pedagang pengumpul. Pengambilan sampel untuk sampel pedagang dilakukan dengan menggunaka metode snowball sampling, yaitu dengan mengikuti alur pemasaran pinang yang dominan di daerah penelitian berdasarkan informasi yang didapat dari pelaku pasar sebelumnya (petani pinang). Jumlah pedagang sampel yang diperoleh terdiri dari 10 orang PPK dan 8 orang PPB.

Berdasarkan hasil kajian yang telah dilakukan, pola saluran pemasaran pinang yang terbentuk terdiri dari 3 saluran pemasaran yaitu :

Saluran pemasaran I : petani-PPB-perusahaan eskportir

Saluran pemasaran II : petani-PPK-PPB-perusahaan eksportir

Saluran pemasaran III : petani-PPK-perusahaan eksportir

Gambaran saluran pemasaran pinang di Kecamatan Betara Kabupaten Tanjung Jabung Barat dapat dilihat sebagai berikut:

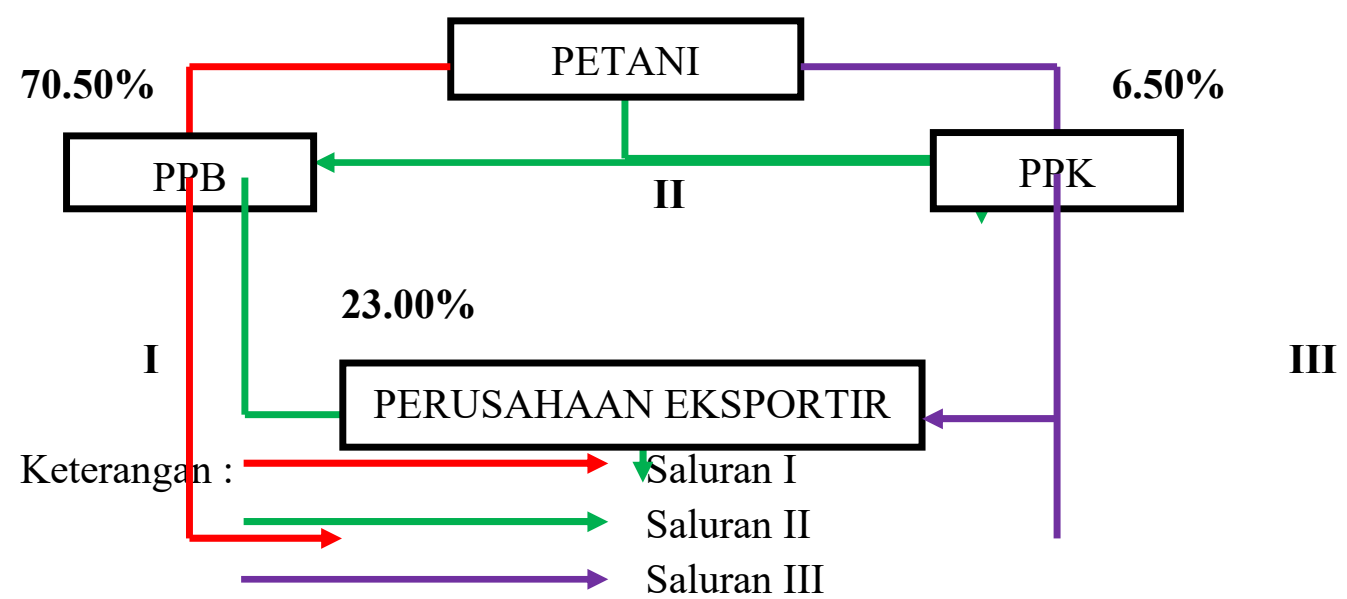

Gambar 2. Saluran Pemasaran Pinang di Kecamatan Betara Kabupaten Tanjung Jabung Barat Tahun 2017

\section{Fungsi-Fungsi Lembaga Pemasaran Pinang}

Menurut Anindita (2004) menyatakan bahwa fungsi pemasaran adalah kegiatan utama yang khusus dilaksanakan untuk menyelesaikan proses pemasaran. Fungsi pemasaran biasanya dilakukan untuk mengurangi hambatan-hambatan terkait waktu, jarak, lokasi dan kurangnya informasi pasar. Adapun fungsi-fungsi pemasaran menurut Asmarantaka (2014) meliputi fungsi pertukaran, fungsi fisik dan fungsi fasilitas yang mana fungsi pertukaran 
merupakan aktivitas dalam perpindahan hak milik barang/jasa yang terdiri dari fungsi pembelian, penjualan, dan fungsi pengumpulan, sedangkan fungsi fisik merupakan aktivitas penanganan, pergerakan dan perubahan fisik dari produk/jasa serta turunannya. Fungsi ini membantu menyelasikan permasalahan dari pemasaran seperti kapan, apa dan dimana pemasaran tersebut terjadi.

\section{Petani}

Berdasarkan fungsi pertukaran yang dilakukan adalah fungsi penjualan. Pada umumnya fungsi penjualan dilakukan oleh petani ke pedagang perantara (PPB dan PPK). Fungsi fisik yang dilakukan petani meliputi pengangkutan dan pengeringan. Pada pola saluran I, fungsi pengangkutan yang dilakukan yaitu saat petani mengantarkan hasil panennya kepada PPB dengan menggunakan kendaraan bermotor yang dilengkapi dengan keranjang ataupun karung. Fungsi pengeringan dilakukan secara sederhana, yaitu setelah pinang dipanen pinang dibelah menjadi dua dicongkel bijinya kemudian dijemur, dan untuk pinang yang telah jatuh dari pohonnya langsung dijemur utuh.

\section{Pedagang Pengumpul Besar (PPB)}

Pada umumnya pedagang pengumpul besar (PPB) menjemput pinang di tempat petani jika volume pinang cukup besar menggunakan mobil pick up. Fungsi fasilitas yang dilakukan adalah sortasi/grading, resiko, pembiayaan dan informasi pasar. Berdasarkan hasil di daerah penelitian pedagang juga melakukan grading yaitu pengelompokkan komoditas pinang berdasarkan kualitasnya. Semua pinang yang telah kering dikemas dalam karung dengan berat 20 dan $50 \mathrm{~kg}$ per karungnya. Pinang yang kualitasnya kurang baik dipisahkan dan dijual ke perusahaan eksportir dengan harga yang cukup rendah dari harga pasaran. Fungsi penanggungan resiko yang dihadapi oleh PPB adalah penurunan harga jual pinang maupun penyusutan berat biji pinang yang telah kering. Fungsi pembiayaan yang dilakukan meliputi biaya transportasi dan upah tenaga kerja. Sedangkan fungsi informasi pasar yaitu berupa informasi mengenai perkembangan harga yang diperoleh dari lembaga-lembaga pemasaran yang terlibat. Hal ini juga sebanding dengan hasil penelitian Harahap (2010) yang mana pedagang melakukan semua fungsi pemasaran dimana salah satunya adalah kopi gelondong diolah menjadi kopi ready. Kemudian dikemas menggunakan karung $108 \mathrm{~kg}$ dan dijual ke pedagang pengumpul II atau ke eksportir.

\section{Pedagang Pengumpul Kecil (PPK)}

Berbeda dengan pedagang pengumpul besar (PPB) yang mengumpulkan pinang dari petani dan PPK, PPK biasanya hanya membeli pinang dari petani dan langsung mendatangi petani. Jumlah yang dibeli PPK juga berbeda dengan PPB. Jika PPB mengumpulkan sebanyak mungkin dari petani, PPK hanya membeli pinang sesuai dengan kapasitas penyimpanan/penjemuran mereka. Pinang yang dibeli dari petani selanjutnya diantarkan ke PPB namun adapula sebagian kecil PPK yang langsung mengantarkan ke perusahaan eksportir. Menurut Asmarantaka (2014) fungsi-fungsi pemasaran meliputi fungsi pertukaran, fungsi fisik dan fungsi fasilitas. Hal ini sejalan dengan hasil penelitian dilapangan yaitu PPK juga melakukan fungsi fisik (pengangkutan dan pengeringan) dan fungsi fasilitas (fungsi penanggungan resiko, fungsi pembiayaan dan fungsi informasi pasar). 


\section{Efisiensi Lembaga Pemasaran Pinang}

Efiensi Lembaga pemasaran dapat tercapai apabila sistem pemasaran yang dijalankan memberi kepuasan kepada pelaku-pelaku pemasaran yang terlibat didalamnya seperti petani dan lembaga pemasaran lainnya. Efisien tidaknya suatu sistem pemasaran dapat diketahui dari beberapa indikator, diantaranya struktur pasar yang dihadapi, perilaku pasar, dan kinerja yang dilihat dari sebaran marjin pemasaran, bagian harga yang diterima petani (farmer's share), dan rasio keuntungan biaya. Berdasarkan indikator-indikator SCP dapat diketahui bahwa pemasaran pinang di Kecamatan Betara belum efisien. Hal ini sesuai dengan indikator dan analisis pemasaran SCP (Khols dan Uhl, 2002) bahwa tidak efisiennya suatu sistem pemasaran dicirikan dengan jumlah pedagang yang sedikit dan hambatan masuk pasar yang sulit, harga yang ditentukan secara sepihak, dan share petani yang kecil. Efisiensi pemasaran dengan pendekatan Structure, Conduct, and Performance (SCP) akan dijelaskan sebagai berikut.

\section{Analisis Struktur Pasar (Structure Market)}

Struktur pasar yang terbentuk pada setiap lembaga pemasaran berbeda-beda dan dapat menentukan tingkat efisiensi dari suatu pemasaran. Berdasarkan hasil penelitian di lapangan, struktur pasar dianalisis dengan melihat jumlah penjual dan pembeli, diferensiasi produk dan hambatan keluar masuk pasar. Struktur pasar secara keseluruhan dalam proses pemasaran pinang di Kecamatan Betara cenderung mengarah kepada kepada struktur pasar oligopsoni. Hal ini dicirikan dengan jumlah penjual dan pembeli yang tidak sebanding, tidak ada diferensiasi produk, petani sebagai price taker, dan hambatan keluar masuk pasar. Hal ini tidak sebanding dengan penelitian Amalia (2013) yang menyatakan bahwa hasil analisis konsentrasi pasar (CR4) menunjukkan bahwa terdapat empat perusahaan terbesar yang menguasai $75,70 \%$ dari total penjualan karet di Provinsi Jambi artinya tingkat persaingan pabrik crumb rubber di Provinsi Jambi terkonsentrasi dengan tingkat persaingan kecil. Kondisi ini juga menggambarkan bahwa pasar karet rakyat di tingkat pabrik crumb rubber di Provinsi Jambi cenderung berada dalam struktur pasar oligopoli.

\section{Pedagang Pengumpul Besar (PPB)}

Pedagang Pengumpul Besar (PPB) yang dijadikan sampel dalam saluran ini terdiri dari 8 orang. Menurut Asmarantaka (2014) struktur pasar monopsoni adalah pasar yang dikuasai satu pembeli dan apabila perusahaan itu bukan sebagai penjual tetapi sebagai pembeli tunggal, dengan ciri-ciri hanya ada satu pembeli, pembeli bukan konsumen tapi/pedagang atau produsen, barang yang dijual merupakan bahan mentah dan harga sangat ditentukan oleh pembeli. Pernyataan tersebut sesuai dengan hasil penelitian dil lapangan yang mana struktur pasar yang dilakukan PPB terhadap pasar tujuan mengarah pada struktur pasar monopsoni. Hal itu ditandai dengan hanya ada satu pembeli, tidak ada diferensiasi produk, adanya informasi pasar kemudian adannya hambatan keluar masuk pasar. Hambatan yang terjadi pada pasar ini adalah pedagang pengumpul yang memasuki pasar membutuhkan modal yang cukup besar. Hal ini dikarenakan sebagian besar lembaga pemasaran yang sudah menjadi 
pelanggannya tidak langsung membayar pinangnya. Hal ini menyulitkan PPB untuk melakukan pembayaran kepada petani.

\section{Pedagang Pengumpul Kecil (PPK)}

Menurut hasil penelitian dari Widyaningtiyas (2014) Ditingkat tengkulak dengan pedagang pengumpul desa, tengkulak dalam pemasaran kopi arabika lebih banyak dibandingkan pedagang pengumpul desa sehingga struktur pasar pada tingkat ini dilihat dari sisi pembeli yang lebih sedikit dari penjual merupakan struktur pasar oligopsoni. Hal tersebut juga sebanding dengan hasil penelitian di lapangan yaitu struktur pasar yang dihadapi oleh pedagang pengumpul kecil (PPK) mengarah kepada struktur pasar oligopsoni dimana jumlah penjual yang banyak serta tidak ada diferensiasi produk kemudian hambatan keluar masuk pasar relatif besar. Dalam memperoleh pinang PPK langsung mendatangi petani yang telah memanen pinangnya dengan melakukan pembayaran tunai pada saat transaksi. Hal ini tentu menyebabkan PPK harus memiliki modal yang cukup ketika memasuki pasar. Karakteristik struktur pasar dapat dilihat pada Tabel 7.

Tabel 7. Analisis Pemasaran Lembaga-lembaga Pemasaran Pinang dengan Pendekatan Struktur Tahun 2017

\begin{tabular}{cccccc}
\hline $\begin{array}{c}\text { Lembaga } \\
\text { Pemasaran }\end{array}$ & $\begin{array}{c}\text { Jumlah } \\
\text { Penjual }\end{array}$ & $\begin{array}{c}\text { Jumlah } \\
\text { Pembeli }\end{array}$ & $\begin{array}{c}\text { Diferensiasi } \\
\text { Produk }\end{array}$ & Hambatan & $\begin{array}{c}\text { Struktur } \\
\text { Pasar }\end{array}$ \\
\hline Petani & 61 & 18 & Tidak ada & ada & Oligopsoni \\
PPB & 8 & 1 & Tidak ada & ada & Monopsoni \\
PPK & 10 & 9 & Tidak ada & ada & Oligopsoni \\
\hline
\end{tabular}

Melihat jumlah penjual dan pembeli yang tidak sebanding, maka pemasaran pinang di Kecamatan Betara adalah tidak efisien, karena beberapa tingkat pasar ini hampir semuanya mengarah pada pasar oligopsoni, hanya satu tingkat pasar pada PPB yang struktur pasarnya mengarah pada pasar monopsoni. Berdasarkan pada paradigma SCP, struktur pasar yang efisien adalah pasar persaingan sempurna. Pasar yang bersaing sempurna dapat menciptakan sistem pemasaran efisien karena pasar yang bersaing sempurna memberikan insentif bagi partisipasi pasar yaitu produsen, lembaga pemasaran, dan konsumen (Rahim, 2007).

\section{Praktek Penjualan Pinang di Tingkat Petani}

Petani yang menjual ke PPK adalah petani yang enggan untuk mendatangi pedagang. Karena PPK biasanya langsung mengambil pinang dari tempat tinggal mereka dan mau membeli pinang dalam keadaan basah. Ada juga sebagian kecil petani yang menjual pinang ke PPK karena adanya keterikatan, baik keluarga maupun hutang. Hal itu lah yang menyebabkan petani menjual pinang ke PPK. Hal tersebut sejalan atau sebanding dengan hasil penelitian Abubakar (2016) yang mana kegiatan pemasaran biji kakao dilakukan oleh petani ketika biji kakao telah di ambil dari buahya kemudian dijemur terlebih dahulu, kemudian PPD dan PPK mengambil pinang kerumah petani. 


\section{Praktek Penjualan dan Pembelian Pinang di Tingkat Pedagang}

Berdasarkan hasil pengkajian di lapangan pedagang pengumpul besar (PPB) dan pedagang pengumpul kecil (PPK) melakukan penjualan setiap pinang telah dirasa cukup dan kadarnya airnya telah mencapai $0.5 \%$. Hal ini dikarenakan PPB dan PPK ingin meminimalkan biaya transport atau pun pengangkutan, maka PPB dan PPK memasarkan pinang jika telah terkumpul banyak dan harga yang diterima cukup tinggi. Umumnya PPB langsung memasarkan atau menyalurkan pinang dari petani ke perusahaan eskportir, tapi ada juga PPK yang terlebih menyalurkan pinang ke PPB kemudian dari PBB menyalurkan pinang ke perusahaan eksportir. Namun ada sebagian kecil dari PPK yang juga langsung menyalurkan pinang ke perusahaan eksportir. PPK yang menyalurkan pinang langsung ke perusahaan eksportir membutuhkan modal yang cukup besar dikarenakan adanya biaya transport dan pengeringan. Hal ini juga sebanding atau sejalan dengan hasil penelitian Abubakar (2016) dan Amalia (2013) PPB dan PPK melakukan penjualan ketika telah memperoleh biji kakao kering yang cukup untuk dijual ke pedagang selanjutnya.

\section{Sistem Penentuan Harga dan Pembayaran Harga}

Berdasarkan hasil penelitian di lapangan yaitu harga yang terbentuk dalam pemasaran pinang antara petani dengan lembaga-lembaga pemasaran ditentukan dengan melalui mekanisme pasar dan hasil interaksi antara penawaran dan permintaan sehingga petani dan pedagang di pasar ini tidak dapat mempengaruhi harga dan hanya berperan sebagai penerima harga (price taker). Petani yang menjual pinang kepada PPB dan PPK dapat langsung menerima hasil penjualan pada saat itu. Harga yang ditetapkan oleh PPB dan PPK dibedakan berdasarkan kualitas pinang. Pinang yang kualitasnya kurang bagus dibeli dari petani dengan harga di bawah rata-rata pasar.

Tabel 8. Sistem Penentuan dan Pembayaran Harga Tahun 2017

\begin{tabular}{|c|c|c|c|}
\hline $\begin{array}{c}\text { Lembaga } \\
\text { Pemasaran }\end{array}$ & $\begin{array}{c}\text { Tujuan } \\
\text { Penjualan }\end{array}$ & Proses Penentuan Harga & $\begin{array}{c}\text { Sistem Pembayaran } \\
\text { Harga }\end{array}$ \\
\hline \multirow[t]{2}{*}{ Petani } & PPB & Ditentukan oleh PBB & Tunai \\
\hline & PPK & Ditentukan oleh PPK & Tunai \\
\hline PPB & P. Eksportir & $\begin{array}{l}\text { Ditentukan oleh P. } \\
\text { Eksportir }\end{array}$ & $\begin{array}{l}\text { Tunai/Pembayaran } \\
\text { Kemudian }\end{array}$ \\
\hline \multirow[t]{2}{*}{ PPK } & PPB & Ditentukan oleh PBB & Tunai \\
\hline & P. Eksportir & $\begin{array}{l}\text { Ditentukan oleh P. } \\
\text { Eksportir }\end{array}$ & Tunai \\
\hline
\end{tabular}

Pada Tabel 8 dapat dilihat bahwa harga ditentukan oleh PPB, PPK dan perusahaan eksportir akan tetapi sistem pembayaran yang dilakukan cukup beragam. Hal ini sesuai dengan penelitian Abubakar (2016) yang menyatakan bahwa terdapat 2 sistem pembayaran yang ditemukan, yaitu sistem pembayaran tunai dan pembayaran kemudian. Bagi PPB yang sudah berlangganan dengan perusahaan eksportir tentu sudah terjalin kerjasama yang baik mulai dari penyediaan barang sampai dengan sistem pembayarannya. Adapula perusahaan eksportir yang langsung melakukan pembayaran tunai bahkan pembayaran 1-4 kali dalam 
sebulan. Namun PPB dan PPK tetap melakukan pembayaran tunai kepada petani setelah menerima pinang dari petani.Biaya pemasaran pinang terdiri dari biaya pengangkutan, upah bongkar muat, retribusi jalan, penyusutan, penyimpanan dan keuntungan pedagang. Berdasarkan hasil penelitian Abubakar (2016) analisis marjin pemasaran dilakukan mulai dari petani, pedagang pengumpul desa, pedagang pengumpul kecamatan, pedagang besar provinsi dan eksportir. Besarnya marjin pada pola saluran I dapat dilihat pada tabel 9 berikut ini:

Tabel 9. Marjin Pemasaran Pola Saluran I Tahun 2017

\begin{tabular}{lr}
\hline Lembaga Pemasaran & Harga (Rp/Kg) \\
\hline Petani & $10.372,00$ \\
Harga Jual & \\
PPB & \\
Harga Beli & $10.372,00$ \\
Biaya Pemasaran & 255,29 \\
Keuntungan & $4.622,71$ \\
Harga Jual & $15.250,00$ \\
Marjin & $\mathbf{4 . 8 7 8 , 0 0}$ \\
\hline Rasio Keuntungan dan
\end{tabular}

\section{Rasio Keuntungan dan Biaya}

Rasio keuntungan dan biaya merupakan salah satu alat ukur efisiensi pemasaran yang digunakan untuk melihat sebaran keuntungan dan biaya yang dikeluarkan oleh lembaga pemasaran. Menurut Asmarantaka (2014) berdasarkan nilai marjin pemasaran yang diperoleh dapat diketahui tingkat rasio keuntungan terhadap biaya yang dikeluarkan oleh lembaga pemasaran. Rasio ini menunjukkan besarnya keuntungan yang diperoleh terhadap biaya pemasaran yang dikeluarkan oleh masing-masing lembaga pemasaran (Tabel 10) dibawah ini.

Tabel 10. Rasio Keuntungan dan Biaya pada Saluran Pemasaran Pinang Tahun 2017

\begin{tabular}{lccc}
\hline \multicolumn{1}{c}{$\begin{array}{c}\text { Lembaga } \\
\text { Pemasaran }\end{array}$} & $\begin{array}{c}\text { Keuntungan } \\
(\mathbf{R p} / \mathbf{K g})\end{array}$ & Biaya $(\mathbf{R p} / \mathbf{K g})$ & $\boldsymbol{\pi} / \mathbf{C}$ \\
\hline $\begin{array}{l}\text { Saluran I } \\
\text { PPB }\end{array}$ & 4622,71 & 255,29 & 18,11 \\
Saluran II & & & \\
PPK & 1915,39 & 173,61 & 11,96 \\
PPB & 5272,67 & 252,33 & 20,91 \\
Saluran III & & & \\
PPK & 4612,18 & 387,82 & 11,89 \\
\hline
\end{tabular}

Berdasarkan Tabel 10 rasio keuntungan atas biaya pada setiap saluran pemasaran pinang memiliki nilai lebih dari satu, hal ini menunjukan bahwa kegiatan pemasaran yang dilakukan oleh lembaga masing-masing saluran pemasaran sudah memberikan keuntungan. Menurut Asmarantaka (2014) Semakin tinggi nilai rasio semakin besar keuntungan yang diperoleh. Jika nilai $\pi / \mathrm{C}$ lebih dari satu $(\pi / \mathrm{C}>1)$ maka kegiatan pemasaran tersebut menguntungkan, sebaliknya jika nilai $\pi / \mathrm{C}$ kurang dari satu $(\pi / \mathrm{C}<1)$ maka kegiatan pemasaran tersebut tidak memberikan keuntungan. Hal tersebut sesuai dengan hasil pengkajian di lapangan yang mana 
nilai $\pi / \mathrm{C}$ tertinggi terdapat pada pola saluran pemasaran II (petani-PPK-PPB-perusahaan eksportir) pada pihak PBB yaitu 20,91, artinya jika lembaga pemasaran pada saluran pemasaran mengeluarkan biaya sebesar $\mathrm{Rp} 1 / \mathrm{Kg}$ maka keuntungan yang diperoleh sebesar Rp20,91/Kg, sedangkan pola saluran pemasaran III (petani-PPK-perusahaan eksportir) nilai rasio keuntungan atas biaya memiliki nilai yang paling rendah yaitu dengan nilai 11,89 . Hal tersebut berarti bahwa dari setiap $\mathrm{Rp} 1 / \mathrm{Kg}$ biaya pemasaran yang dikeluarkan oleh PPK yang bersangkutan akan menghasilkan keuntungan sebesar Rp11,89/Kg. Dari hasil pengkajian tersebut dapat diperoleh kesimpulan bahwa rasio keuntungan biaya memberikan keuntungan karena dari ketiga saluran pemasaran tersebut semuanya $(\pi / \mathrm{C}>1)$.

\section{KESIMPULAN}

Pemasaran pinang di Kecamatan Betara terdiri dari tiga pola saluran pemasaran, yaitu : 1) petani-PPB-perusahaan eksportir ; 2) petani-PPK-PPB-perusahaan eksportir ; 3) petani-PPKperusahaan eksportir. Berdasarkan struktur pasar, pemasaran pinang di Kecamatan Betara cenderung mengarah kepada struktur pasar oligopsoni yang termasuk pada kategori pasar persaingan tidak sempurna. Dilihat dari perilaku pasar, lembaga pemasaran yang terlibat memiliki perilaku yang berbeda-beda. Harga yang terbentuk dalam pemasaran pinang antara petani dengan lembaga-lembaga pemasaran ditentukan dengan melalui mekanisme pasar dan hasil interaksi antara penawaran dan permintaan sehingga petani dan pedagang di pasar ini tidak dapat mempengaruhi harga dan hanya berperan sebagai penerima harga (price taker). Sistem pembayaran yang diterima petani dari PPB dan PPK adalah sistem pembayaran tunai. Sedangkan berdasarkan kinerja pasar menunjukkan bahwa nilai marjin, farmer's share, dan rasio keuntungan tidak merata pada masing-masing lembaga pemasaran. Dari indikator SCP yang telah dijelaskan di atas dapat diketahui bahwa pemasaran pinang di Kecamatan Betara belum efisien. Berdasarkan kondisi saat ini dan hasil analisis yang telah dilakukan, saluran pemasaran III (petani-PPK-perusahaan eksportir) merupakan alternatif saluran pemasaran yang efisien yang dapat dipilih oleh petani untuk menjual pinangnya. Hal tersebut didasarkan pada hasil analisis yang telah dilaksanakan pada pola saluran pemasaran yang terbentuk, kemerataan fungsi-fungsi pemasaran, struktur pasar yang dihadapi, perilaku pasar, dan keragaan pasar yang diukur dari nilai marjin pemasaran, farmer's share, dan rasio keuntungan atas biaya-biaya. Dari hasil dan pembahasan yang telah dijelaskan sebelumnya sebaiknya petani yang ingin meningkatkan pendapatannya sebaiknya memilih ataupun beralih ke saluran I.

\section{DAFTAR PUSTAKA}

Abubakar, Ihdiani. 2016. Analisis Structure, Conduct dan Performance Pada Pasar Kakao: Kasus Di Kabupaten Parigi Moutong Provinsi Sulawesi Tengah. [Tesis]. Sekolah Pascasarjana. Institut Pertanian Bogor. Bogor.

Ali, Hasan. 2008. Marketing. Media Pressindo. Yogyakarta. 
Amalia, Dwi Nurul. 2013. Sistem Pemasaran Karet Rakyat Di Provinsi Jambi dengan Pendekatan Struktur, Perilaku, Dan Kinerja Pasar. Jurnal. Departemen agribisnis Fakultas Ekonomi dan Manajemen. Institut Pertanian Bogor. Bogor.

Anindita, R. 2004. Pemasaran Hasil Pertanian. Papyrus, Surabaya.

Anonim. 2013. Prospek budidaya pinang areca catechu.

Anonim. 2008. Budidaya pinang. Surabaya

Asmarantaka, R.W. 2009. Pemasaran Produk-produk Pertanian. Bunga Rampai Agribisnis: Seri Pemasaran. IPB Press, Bogor.

Asmarantaka, R.W. 2014. Pemasaran agribisnis (Agrimarketing). IPB Press. Bogor.

Badan Litbang Pertanian. 2014. Rencana Strategis Badan Penelitian dan Pengembangan Pertanian 2015-2019. Kementerian Pertanian. Badan Litbang Pertanian. Jakarta.

BP3K Kecamatan Betara. 2016. Kelompok Tani Perkebunan. Provinsi Jambi.

BPS Provinsi Jambi. 2016. Jambi Dalam Angka. Provinsi Jambi.

Dinas Perkebunan Kabupaten Tanjung Jabung Barat. 2016. Statistik Perkebunan. Kabupaten

Tanjung Jabung Barat.

Direktorat Jenderal Perkebunan Provinsi Jambi. 2016. Statistik Perkebunan. Provinsi Jambi.

Direktorat Jenderal Perkebunan. 2016. Statistik Perkebunan. Jakarta.

Direktorat Jenderal Perkebunan. 2015. Budidaya Pinang dan Manfaatnya. Provinsi Jawa Timur.

Harahap, Nova Mariani. 2010. Analisis Efisiensi Pemasaran Kopi Arabika (Coffea Arabica)

Di Desa Beranun Teleden Kecamatan Bandar Kabupaten Bener Meriah. [Skripsi].

Fakultas Pertanian. Universitas Sumatera Utara. Medan.

Hernanto, Fadoli.1996. Ilmu Usahatani. penebar Swadaya. Jakarta.

Kohls dan Uhl. 2002. Marketing of Agricultural Products. Ninth Edition. Prentice Hall, New Jersey.

Lutony, Luqman T. 1992. Pinang Sirih. Kanisius. Yogyakarta.

Miftahorrachman. 2013. Jambi Penghasil Komoditi Pinang Terbaik. IAARD Press. Bogor.

Miftahorrachman. 2015. Teknologi Budi Daya dan Pasca Panen Pinang. IAARD Press. Bogor.

Mosher, Athur T. 2011. Membangun Pertanian.CV. Simplex. Jakarta.

Mubyarto. 1995. Pengantar Ekonomi Pertanian. LP3ES. Jakarta.

Nawiruddin, Muhammad. 2017. Dampak Keberadaan Perkebunan Kelapa Sawit Dalam

Peningkatan Pendapatan Masyarakat Di Kecamatan Long Kali Kabupaten Paser.

Universitas Mulawarman. Samarinda.

Nazaruddin. 1993. Komoditi Ekspor Pertanian Tanaman Perkebunan Rempah dan Obat. Penebar Swadaya. Jakarta.

Rahim. 2007. Ekonomika Pertanian. Penebar Swadaya. Depok.

Kementerian Pertanian. 2015. Rencana Strategis Kementerian Pertanian 2015-2019.

Kementerian Pertanian. Jakarta.

Petunjuk pelaksanaan Pendampingan, Pengembangan Kawasan Pertanian Nasional

Komoditas Perkebunan.Badan Penelitian dan Pengembangan Pertanian, 2016. 


\section{Puslitbang Perkebunan. 2016. Program Kegiatan Jangka Menengah 2015-2019. Materi dipaparkan dalam diskusi di Balai Besatr Pengkajian dan Pengembangan Teknologi Pertanian.}

Peraturan Menteri Pertanian No.50./Permentan/CT.140/8/2012. Tentang Pedoman Pengembangan Kawasan Pertanian. Kementerian Pertanian.

Sastrahidajat I. R dan Soemarno D. S. 1986. Budidaya Tanaman Tropika. Faperta Unibraw. Surabaya

Sugiyono, 2014. Metode Penelitian Kualitatif, Kuantitafif dan R\&D. Alfabeta, Bandung.

Sulkani. 2013. Kiat membudidayakan pinang sirih.

Widyaningtyas, D. 2014. Analisis Efisiensi Pemasaran Kopi Arabika Di Desa Karangpring Kecamatan Sukorambi Kabupaten Jember. Jurnal Sosial Ekonomi. Fakultas Pertanian. Universitas Jember. (Diunduh dari repository.unej.ac.id pada 09 April 2017).

Yuyu Yuhannah. 2014. Khasiat buah pinang untuk meningkatkan keperkasaan pria. 